\title{
Morphology characterization of gembili (Dioscorea esculenta L.) Tanimbar, Maluku Province
}

\author{
Marietje Pesireron*, Rein E. Senewe, Abd Gaffar, Edwin D. Waas, and Sheny Kaihatu \\ Assessment Institute for Agricultural Technology Maluku-Indonesia
}

\begin{abstract}
Gembili (Dioscorea esculenta L.) is a tuber of the type (clan) Dioscorea as a $27-37 \%$ carbohydrate producer and has a nutritional composition that varies according to species. The research was conducted from May to December 2019 in Tanimbar Island Regency, Maluku. Using the method of observation and description. The morphological character of the five local accessions showed that the characters of the same plant species were singular and striking, namely the presence of roots on the tuber surface and the location of the roots on the tuber surface. There were spines on the tuber surface, and the weight of the tubers of the five accessions averaged $1.71-2,72 \mathrm{~kg}$ higher than the highest collection at the Genetic Research and Development Center for Agricultural Biotechnology and Genetic Resources, namely accessions R 506 (Lokal Tanatoraja) and R 601 (Lokal Manukan) which only weighed $1,000 \mathrm{~g}$. The five accessions of the Gembili plant have the potential to be developed as an alternative food.
\end{abstract}

\section{Introduction}

Gembili is one of the types of yam plants (cassava, sweet potato, yams and cocoyams) as a source of non-carbohydrate. Rice is a traditional food plant and is a genetic resource for the people of Maluku. Cassava and sweet potato are classified as the main sweet potatoes, while yams (coconut/uwi and Gumbili) and cocoyam (taro and taro) are classified as rare minor yams, because these species are almost extinct and only developed by a small number of local farmers. Genetic erosion that occurs in tubers must be reduced and prevented by all parties. One of the ways to manage genetic resources optimally is by carrying out conservation and characterization activities.

Based on the characterization of the agroecological zone (AZ), the land potential that can be developed for food crops in Maluku (excluding North Maluku) in terms of altitude $(0.750$ $\mathrm{m}$ asl) with a slope $(0-8 \%)$ is 425.998 ha [1-2] only 30,438 ha were utilized so that the potential to be developed was 395,550.4 ha. Apart from the potential for untapped land, there are also a number of lands whose utilization is not optimal and land areas are still neglected. Thus, the development of traditional food crops (sweet potatoes and maize) in Maluku Province in the future still has great opportunities.

\footnotetext{
* Corresponding author: itjepesi@yahoo.com
} 
Potential minor yams (Dioscorea alata coconut / uwi and Dioscorea esculenta Gembili), and cocoyams (Xanthosoma sagittifolium taro, and Colocasia esculenta taro), are types of yams (Dioscorea alata yam, gembili). These tubers are scattered throughout Maluku (including North Maluku), the development area of Central Maluku, Southeast Maluku (including West Southeast Maluku) and North Maluku. The results of the Agricultural Faculty, University of Pattimura Ambon analysis on other edible yam varieties, showed that in the development area of Central Maluku there were at least 70 varieties of yams (Dioscorea spp.) and 7 varieties of cocoyam (Xanthosoma sagittifolium and Colocasia esculenta), in the Maluku development area. Southeast (including West Southeast Maluku) has at least 38 varieties of yams and 16 varieties of cocoyam, while in the development area of North Maluku there are at least 6 varieties of yams and 3 varieties of cocoyam [3].

Gembili (Dioscorea esculenta L.) is a tuber of the type (genus) Dioscorea which has been cultivated by rural communities for a long time, although not en masse. Dioscorea, apart from being a carbohydrate producer, also has ingredients that can be used for various industrial and medicinal purposes [4-5]. Dioscorea contains $25 \%$ starch, $0.1-0.3 \%$ fat and $1.3-2.8 \%$ protein [6]. Apart from being a source of carbohydrates, gembili is also a potential source of hydrate for charcoal, protein, low fat, calcium, phosphorus, potassium, iron, dietary fiber, vitamin B6 and vitamin C [7]. Gembili tubers have a composition of nutritional content that varies according to species and varieties. The largest component of Gembili tubers is carbohydrates, amounting to $27-37 \%$ [8].

Gembili has several advantages and benefits for human health. The advantage of gembili is that it contains food fiber and bioactive compounds, such as inulin [9]. Gembili contains $14.629 \%$ (bk) of inulin. Inulin can reduce the risk of colon cancer, normalize blood sugar levels and help affect decreased heart health and prevent colon cancer [10]. The growth and distribution of these plants are very much and have become a staple food substitute for rice besides sweet potatoes and taro in local communities in Maluku.

This study aims to obtain information about the morphological characters of some Gembili accessions in the Tanimbar Islands Regency. By knowing these morphological characters, we can recognize various types of kumbili in the field and know the potential Gembili as a flour producer and in an effort to preserve it to prevent the extinction of these types of Gembili.

\section{Methodology}

The research was conducted in May until December 2019 in Tanimbar Islands Regency, Kormomolin District, Nirunmas District and Wertamrian District, Tanimbar Islands Regency, Maluku Province using the observation method followed by a description. Altitude ranges from 3 - $243 \mathrm{~m}$ above sea level. Observations were made on five accessions of Gembili namely Gembili Siabu Futmaere, Gembili Siabu Lela, Gembili Siabu Kelapa, Gembili Siabu Safian, and Gembili Siabu Tepung.

The materials used were five accessions found in Meyano Das village, Tanimbar Islands district. The tools used are measuring instruments (meter), the Royal Horticultural Society Color Chart (RHS), cameras, GPS, calipers, digital scales, zipper plastic and field equipment. The number of Gembili plants used in this study were five accessions and each accession was observed. Observation of morphological and production characters was carried out before and after the trees were felled. Samples were taken randomly for each Gembili accession. Observations were made on morphological characters, production and the environment around the sample area. The parameters observed were stem characters (quantitative and qualitative), leaf characters (quantitative and qualitative), and production characters. 


\section{Results and discussion}

\subsection{Characterization of Gembili}

There are three groups of characters observed, namely the characters of plants, leaves and tubers. The plant characters observed were stem type, stem color, stem length, stem diameter and spines at the base of the stem. Leaf characters of thirteen characters were observed. Nine characters were observed including leaf type, leaf tip shape, ear shape, leaf length, leaf width, leaf stalk length, leaf color, young leaf color and old leaf color. The $\mathrm{K}$ characters observed were tuber shape, outer skin color, inner skin color, tuber flesh color, tuber length, tuber diameter, root surface root, tuber surface cracks, tuber surface cracking, number of tubers per plant and weight seed tubers.

The color characters of gembili leaves in collections at the Indonesian Center for Agricultural Biotechnology and Genetic Resource Research and Development (ICABIOGRD) Gene Bank are reported to be light green for young leaves and green for old leaves [11].

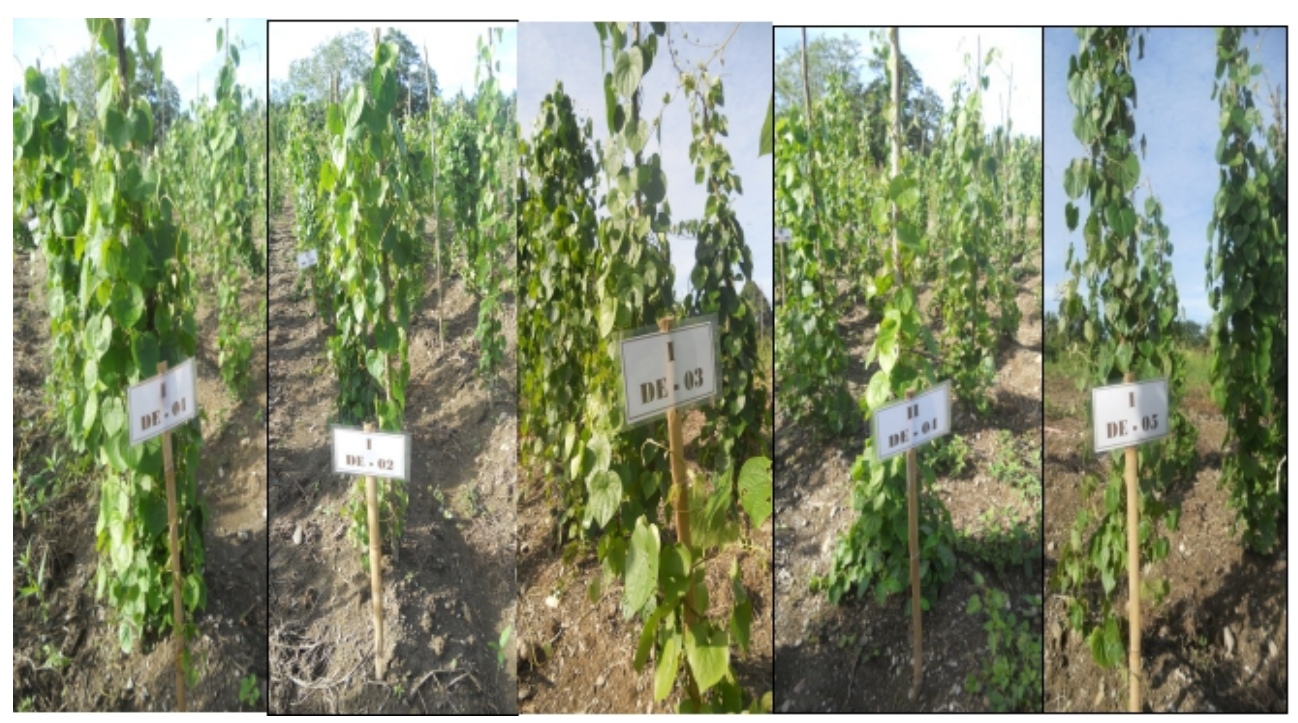

Fig. 1. Appearance of local Gembili plants in Tanimbar Islands Regency

\subsection{Morphological Characters of Gembili in Maluku}

Morphological characteristics are practical guidelines for identifying various types of Gembili in the field. Morphological features that can be observed include stems, leaves and tubers (Table 1). 
Table 1. Character of the Gembili Plant

\begin{tabular}{|l|l|l|}
\hline No & \multicolumn{1}{|c|}{ Character Group } & \multicolumn{1}{c|}{ Character } \\
\hline 1 & Plants (5 characters) & $\begin{array}{l}\text { Stem type, stem color, stem length, stem } \\
\text { diameter and spines at the base of the stem }\end{array}$ \\
\hline 2 & Leaves (9 characters) & $\begin{array}{l}\text { Leaf type, leaf tip shape, ear / base shape, leaf length, leaf } \\
\text { width, stem length, leaf color, young leaf color and old leaf } \\
\text { color }\end{array}$ \\
\hline 3 & Tubers (12 characters) & $\begin{array}{l}\text { Tuber shape, outer skin color, inner skin color, tuber flesh } \\
\text { color, tuber length, tuber diameter, root surface root location, } \\
\text { root location on tuber surface, spines on tuber surface, } \\
\text { cracking on tuber surface, number planting tubers, tuber } \\
\text { weight in crop }\end{array}$ \\
\hline 4 & Other info & $\begin{array}{l}\text { Yield potential, average yield, harvest age and } \\
\text { adaptability }\end{array}$ \\
\hline
\end{tabular}

\subsubsection{Gembili Stems}

The appearance of stem characters, of the five gembili accessions, showed the same results both in the type of stem, stem shape and color of the stem and thorn at the base of the stem. Meanwhile, the average stem length and stem diameter ranged from $153.22-171.11 \mathrm{~cm}$ and $2.37-5.31 \mathrm{~mm}$ (Table 2).

Table 2. Characteristics of the Gembili stems of the five characterized accessions

\begin{tabular}{|c|c|c|c|c|c|}
\hline \multirow[b]{2}{*}{$\begin{array}{c}\text { Stem } \\
\text { Character }\end{array}$} & \multicolumn{5}{|c|}{ Accession Name } \\
\hline & $\begin{array}{c}\text { Siabu } \\
\text { Futmaere } \\
(01)\end{array}$ & $\begin{array}{c}\text { Siabu } \\
\text { Lela } \\
(02)\end{array}$ & $\begin{array}{c}\text { Siabu } \\
\text { kelapa } \\
(03)\end{array}$ & $\begin{array}{c}\text { Siabu } \\
\text { Safian } \\
(04)\end{array}$ & $\begin{array}{c}\text { Siabu } \\
\text { Tepung } \\
\text { (05) }\end{array}$ \\
\hline Type of the stam & $\begin{array}{l}\text { Twisted } \\
\text { climbing }\end{array}$ & $\begin{array}{l}\text { Twisted } \\
\text { climbing }\end{array}$ & $\begin{array}{l}\text { Twisted } \\
\text { climbing }\end{array}$ & $\begin{array}{l}\text { Twisted } \\
\text { climbing }\end{array}$ & $\begin{array}{l}\text { Twisted } \\
\text { climbing }\end{array}$ \\
\hline $\begin{array}{l}\text { The shape of } \\
\text { stem }\end{array}$ & Round & Round & Round & Round & Round \\
\hline The stem color & $\begin{array}{l}\text { Moderate } \\
\text { Yellow } \\
\text { Green }\end{array}$ & $\begin{array}{l}\text { Greyish } \\
\text { Yellow } \\
\text { green }\end{array}$ & $\begin{array}{l}\text { Greyish } \\
\text { Yellow green }\end{array}$ & $\begin{array}{l}\text { Greyish } \\
\text { Yellow } \\
\text { green }\end{array}$ & $\begin{array}{l}\text { Greyish } \\
\text { Yellow } \\
\text { green }\end{array}$ \\
\hline $\begin{array}{l}\text { The length of } \\
\text { stem }(\mathrm{cm})\end{array}$ & 153.22 & 162.22 & 166.11 & 171.11 & 170,67 \\
\hline $\begin{array}{l}\text { Diameter of } \\
\text { stem }(\mathrm{mm})\end{array}$ & 3,55 & 4,45 & 4,74 & 2,37 & 5,31 \\
\hline $\begin{array}{l}\text { Thorn at the } \\
\text { base of stem }\end{array}$ & None & None & None & None & None \\
\hline
\end{tabular}

\subsubsection{Gembili Leaves}

The leaf types of the five accessions are single. Obtuse leaf tip shape. Cordate ear / base shape. The leaves of Siabu Futmaere accession were the longest $(12.90 \mathrm{~cm})$ and Siabu flour was the shortest $(10.83 \mathrm{~cm})$. The width of Gembili leaves for accession Siabu kelapa was widest and the narrowest for accession was Siabu flour. The leaf stalk of Siabu Lela accession is the longest and the shortest stalk is Siabu Lela. The shoot color, young leaf color and old leaf color for Siabu Futmaere and Siabu Lela accessions are strong yellow green The color of the young leaves of the four accessions is the same, namely strong yeloow green, only Siabu Safian is Strong Yellow. The old leaf color for accessions of Siabu 
Futmaere, Siabu Lela and Siabu Tepung was the same, namely strong yellow green, while Siabu kelapa and Siabu safian were moderate yellow green in color (Table 3).

Gembili leaves can be used to fertilize other plants after making green manure, and can also be used as a planting medium for rhizome plants such as galangal, ginger, and ornamental plants [12-13].

Table 3. Character of the gembili leaves of the five characterized accessions

\begin{tabular}{|c|c|c|c|c|c|}
\hline \multirow[b]{2}{*}{ Character Leaf } & \multicolumn{5}{|c|}{ Accession } \\
\hline & $\begin{array}{c}\text { Siabu } \\
\text { Futmaere } \\
(01)\end{array}$ & $\begin{array}{l}\text { Siabu } \\
\text { Lela } \\
(02)\end{array}$ & $\begin{array}{c}\text { Siabu } \\
\text { kelapa } \\
(03)\end{array}$ & $\begin{array}{l}\text { Siabu } \\
\text { Safian } \\
(04)\end{array}$ & $\begin{array}{c}\text { Siabu } \\
\text { Tepung } \\
(05)\end{array}$ \\
\hline Leaf type & Single & Single & Single & Single & Single \\
\hline Leaf tip shape & Obtuse & Obtuse & Obtuse & Obtuse & Obtuse \\
\hline $\begin{array}{l}\text { The shape of the ear / } \\
\text { base of the leaf }\end{array}$ & Cordate & Cordate & Cordate & Cordate & Cordate \\
\hline Leaf length $(\mathrm{cm})$ & 12.90 & 11.77 & 12.73 & 12.73 & 10.83 \\
\hline Leaf width $(\mathrm{cm})$ & 14.60 & 11.73 & 15.03 & 13.27 & 11.03 \\
\hline Petiole length $(\mathrm{cm})$ & 13.00 & 10.5 & 14.50 & 11.8 & 13.70 \\
\hline Leaf top color & $\begin{array}{l}\text { Strong } \\
\text { Yellow } \\
\text { Green }\end{array}$ & $\begin{array}{l}\text { Strong } \\
\text { Yellow } \\
\text { Green }\end{array}$ & $\begin{array}{c}\text { Dark } \\
\text { Greenish } \\
\text { Yellow }\end{array}$ & $\begin{array}{l}\text { Strong } \\
\text { Yellow }\end{array}$ & $\begin{array}{l}\text { Light Yellow } \\
\text { Green }\end{array}$ \\
\hline Young leaf color & $\begin{array}{l}\text { Strong } \\
\text { Yellow } \\
\text { Green }\end{array}$ & $\begin{array}{l}\text { Strong } \\
\text { Yellow } \\
\text { Green }\end{array}$ & $\begin{array}{l}\text { Strong } \\
\text { Yellow } \\
\text { Green }\end{array}$ & $\begin{array}{l}\text { Strong } \\
\text { Yellow }\end{array}$ & $\begin{array}{l}\text { Strong Yellow } \\
\text { Green }\end{array}$ \\
\hline Old leaf color & $\begin{array}{l}\text { Strong } \\
\text { Yellow } \\
\text { Green }\end{array}$ & $\begin{array}{l}\text { Strong } \\
\text { Yellow } \\
\text { Green }\end{array}$ & $\begin{array}{c}\text { Moderate } \\
\text { Yellowish } \\
\text { Green }\end{array}$ & $\begin{array}{l}\text { Moderate } \\
\text { Yellowish } \\
\text { Green }\end{array}$ & $\begin{array}{l}\text { Strong Yellow } \\
\text { Green }\end{array}$ \\
\hline
\end{tabular}

\subsubsection{Gembili Tubers}

Gembili tubers (Dioscorea esculenta) are included in local tubers which have a high fiber content of $6.386 \%$ (bk) [14]. Gembili tubers also contain water-soluble dietary fiber in the form of Water-Soluble Polysaccharides (WSP) and inulin. The thick and gel-forming properties of WSP can inhibit macronutrient absorption and reduce postprandial glucose response, so that it has a hypoglycemic effect [9]. The tuber shape of the three accessions looked the same, namely oval, while the coconut Siabu accession was round and Siabu Safian's accession was round. The outer skin color of the tubers varies from light gray to light brownish gray. The deep skin color and tuber flesh color variations are quite diverse. Inner skin color ranges from light brownish gray found in Siabu Futmaere accessions, pale yellow in Siabu Lela accessions, light yellowish brown in accessions of Siabu kelapa and Siabu Safian and pinkish gray for accessions of Siabu Tepung. Meanwhile, the color of the tuber meat starts from white in the accessions of Siabu Futmaere and Siabu Tepung, while the three accessions of tubers are White to Yellowish white. The length of the tubers of the five accessions was different. Accession Siabu kelapa and Siabu flour have the same tuber length and the longest $(20.42 \mathrm{~cm})$. The shortest tuber length is Siabu Lela accession (15.06 $\mathrm{cm})$. The widest tuber diameter is Siabu Lela accession $(39.72 \mathrm{~cm})$ and the smallest diameter is Siabu Safian accession $(20.65 \mathrm{~cm})$. On the surface appearance of the tubers there are rough, smooth, and smooth-coarse and for roots on the surface of the tubers for accessions Siabu Futmaere and Siabu Safian there are no roots while the other three accessions have many roots and the location of the roots is different all over the tuber surface and there are no root. The character of thorns on the tuber surface and cracks on the tuber surface showed 
a uniform result of the 3 accessions (Seabu Futmaere, Seabu Lela and Seabu Safian) were absent while 2 accessions were present (Seabu Kelapa and Seabu flour) (Table 4).

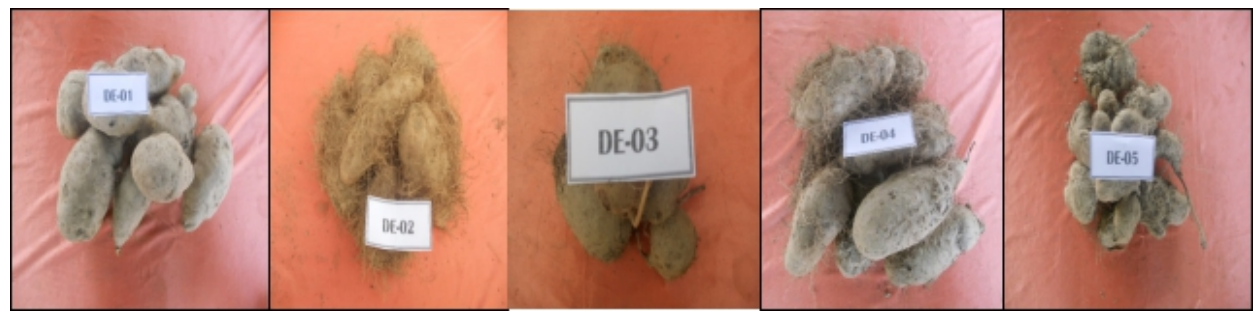

Fig.2. Appearance of Local Gembili tubers in Tanimbar Islands Regency

Kumbili tubers have a composition of nutritional content that varies according to species and varieties [13]. The Siabu Safian and Siabu flour accessions had a larger number of tubers, respectively, 18 and 16 compared to the other accessions. Siabu Tepung's tuber weight is heavier, reaching $2.72 \mathrm{~kg}$, followed by Siabu Safian $(1.855 \mathrm{~kg})$ and has the potential to be released as a superior variety. The tuber weights of the five accessions found in the Tanimbar Islands Regency were higher than the weight of the Yara Hasai tubers from Papua (2000 g) and the existing collections at the Indonesian Center for Agricultural Biotechnology and Genetic Resource Research and Development (ICABIOGRD)Gene Bank, namely accessions R 506 (Lokal Tanatoraja) and R 601 (Lokal Manukan ) which only weighs $1000 \mathrm{~g}$ [13].

Table 4. Character Gembili tuber of the five characterized accessions

\begin{tabular}{|c|c|c|c|c|c|}
\hline \multirow[b]{2}{*}{ Bulbs Character } & \multicolumn{5}{|c|}{ Accession Name } \\
\hline & $\begin{array}{c}\text { Siabu } \\
\text { Futmaere } \\
(01) \\
\end{array}$ & $\begin{array}{c}\text { Siabu } \\
\text { Lela } \\
(02) \\
\end{array}$ & $\begin{array}{c}\text { Siabu } \\
\text { kelapa } \\
(03) \\
\end{array}$ & $\begin{array}{c}\text { Siabu } \\
\text { Safian } \\
(04) \\
\end{array}$ & $\begin{array}{c}\text { Siabu Tepung } \\
(05)\end{array}$ \\
\hline Tuber shape & Oval & Oval & Oval Round & Round & Oval \\
\hline $\begin{array}{l}\text { Outer skin color of } \\
\text { tuber }\end{array}$ & Light Grey & $\begin{array}{l}\text { Moderate } \\
\text { Orange Yellow }\end{array}$ & $\begin{array}{l}\text { Moderate } \\
\text { Orange Yellow }\end{array}$ & $\begin{array}{l}\text { Light Olive } \\
\text { Brown }\end{array}$ & $\begin{array}{l}\text { Light Brownish } \\
\text { Grey }\end{array}$ \\
\hline Skin color in tubers & $\begin{array}{l}\text { Light } \\
\text { Brownish } \\
\text { Grey }\end{array}$ & Pale Yellow & $\begin{array}{l}\text { Light Yellowish } \\
\text { Brown }\end{array}$ & $\begin{array}{l}\text { Light Yellowish } \\
\text { Brown }\end{array}$ & Pinkish Grey \\
\hline $\begin{array}{l}\text { The color of the tuber } \\
\text { flesh }\end{array}$ & Yellowish & $\begin{array}{l}\text { Yellowish } \\
\text { White }\end{array}$ & $\begin{array}{l}\text { Yellowish } \\
\text { White }\end{array}$ & $\begin{array}{l}\text { Yellowish } \\
\text { White }\end{array}$ & Yellowish \\
\hline Tuber length & 17.50 & 15.06 & 20.42 & 15.33 & 20.42 \\
\hline Tuber diameter & 38.61 & 39.72 & 24.70 & 20.65 & 24.70 \\
\hline $\begin{array}{l}\text { Root surface of the } \\
\text { tuber }\end{array}$ & Nothing & Much & Much & Nothing & Much \\
\hline $\begin{array}{l}\text { The location of the } \\
\text { roots on the tuber } \\
\text { surface }\end{array}$ & Nothing & $\begin{array}{l}\text { The entire } \\
\text { surface }\end{array}$ & $\begin{array}{l}\text { The entire } \\
\text { surface }\end{array}$ & Nothing & $\begin{array}{l}\text { The entire } \\
\text { surface }\end{array}$ \\
\hline $\begin{array}{l}\text { Thorns on the surface } \\
\text { of the tuber }\end{array}$ & Nothing & Nothing & Available & Nothing & Available \\
\hline $\begin{array}{l}\text { Cracked on tuber } \\
\text { surface }\end{array}$ & Nothing & Nothing & Available & Nothing & Available \\
\hline $\begin{array}{l}\text { Number of tubers per } \\
\text { plant }\end{array}$ & 11 & 11 & 12 & 19 & 16 \\
\hline $\begin{array}{l}\text { Tuber weight per } \\
\text { plant }(\mathrm{kg})\end{array}$ & 1.730 & 1.730 & 1.712 & 1.855 & 2.722 \\
\hline
\end{tabular}

Dioscorea tubers generally contain thick mucus consisting of glycoproteins and watersoluble polysaccharides, which are bioactive materials that function as water-soluble and hydrocolloid food fibers which are useful for reducing blood glucose levels and total 
cholesterol levels (TCL) [15]. Water-soluble polysaccharides contained in gembili can be used as food additives that function as emulsion stabilizers, gels, foam formers and as fillers [16]. Soluble dietary fiber (SDF) in gembili tubers consists of water-soluble polysaccharides (WSP) and inulin. The ethanol extract of gembili has anticancer activity which significantly influences the development cycle of breast cancer cells [16].

\section{Weed, pest and disease control}

In the observation field many types of broadleaf weeds, ciplokan, nuts, babodotan, meniran merah, manirang putih, nutmeg, and narrow leaves were found but they were controlled by manual weeding and heaped to form a whisk. Yams (yams and kumbili) are plants that are relatively free of pests and diseases. However, in areas with intensive cultivation, pests and diseases are common [17]. The main pests are yam beetle borer (Hetroligus meles and Palalopus dioscoreae) and earthworms (Meloidogyne spp and Pratylanchus spp). These pests can be controlled in an integrated manner, namely environmental sanitation (weeding), soil loosening, crop rotation, schedule planting tubers slower than usual. The main diseases of yams are broom disease (Phyllentypa dioscareae virus and Goplana dioscoreae) and can be controlled in an integrated manner, namely planting resistant varieties, crop rotation, environmental sanitation (weeding), soil loosening, and spraying with fungicides Dethane. Other pests are yam scale (Aspidella hartii) and mealy ugs which attack tubers especially when stored. The important nematodes that often appear are clubroot nematodes (root-knot nematode Maloidogyne spp) and yam nematodes (Scutellonema bradys). The nematodes attack the growing plants and cause spots on crop tubers. Indirectly, local farmers have taken precautions to break their life cycle by rotating and intercropping crops with beans, chilies, sweet potatoes, corn and taro so that it does not experience crop failure. Wild animals such as wild boar and rats can destroy crops. Meanwhile, the common disease is rust disease (Goplana dioscoreae) and another disease is mosaic which is caused by mosaic virus but never controlled by using pesticides, nematicides and fungicides. The control is carried out by farmers by selecting good tubers from truly healthy plants [18].

Table 5. Yield potential, yield average and age of harvest

\begin{tabular}{|l|c|c|c|c|c|}
\hline \multirow{2}{*}{ Other Info } & \multicolumn{5}{|c|}{ Accession Name } \\
\cline { 2 - 6 } & $\begin{array}{c}\text { Siabu } \\
\text { Futmaere }\end{array}$ & $\begin{array}{c}\text { Siabu } \\
\text { Lela }\end{array}$ & $\begin{array}{c}\text { Siabu } \\
\text { kelapa }\end{array}$ & $\begin{array}{c}\text { Siabu } \\
\text { Safian }\end{array}$ & $\begin{array}{c}\text { Siabu } \\
\text { Tepung }\end{array}$ \\
\hline Yield potential $\left(\mathrm{t} \mathrm{ha}^{-1}\right)$ & 43.02 & 43.02 & 50.431 & 45.83 & 67.56 \\
\hline Average yield $\left(\mathrm{t} \mathrm{ha}^{-1}\right)$ & 39.47 & 39.47 & 45.22 & 41.14 & 56.75 \\
\hline Harvest age (months) & 7 & 7 & 7 & 7 & 7 \\
\hline
\end{tabular}

\section{Potential results}

The observations of the five local accessions of gembili / seabu in Tanbimbar show that gembili or seabu has a very high yield potential and average yield (Table 5). According yolk is a very high carbohydrate producer (85.8\%) when compared to rice. As an alternative food, it needs to be more socialized and cultivated by the Indonesian people, especially in Maluku and Papua which are not rice-producing areas. The production of gembili tubers can reach $60-70 \mathrm{t} \mathrm{ha}^{-1}$ on the year, compared to rice whose production is around $5-10 \mathrm{tha}^{-1}$ in planting season, so that for two to three times a year it can be obtained around 15-30 $\mathrm{t} \mathrm{ha}^{-1}$ [13]. From this comparison, it can be seen that the potential production of gembili in a year exceeds rice by up to two times and is expected to become an alternative staple food commodity to replace rice. The five accessions of gembili can grow and are very adaptable to the environment with 
moderate - well drained, light - rather heavy soil structure, lowland - medium Dry land dry climate and wet climate.

\section{Conclusion}

The appearance of the morphological characters of the five local gembili accessions in the Tanimbar Islands District shows that the characters of the same plant type are single, while what is very striking is the presence of roots on the surface of the tubers and the location of the roots on the surface of the tubers, there are many accessions of Seabu Lela, Seabu Kelapa and Seabu Tepung and the weight of the tubers of to the five accessions, an average of 1.71 $-2.72 \mathrm{~kg}$. Yield potential ranges from $43.02-67.56 \mathrm{tha}^{-1}$. The plant is very adaptable to the environment with moderate to good drainage, light soil structure until rather heavy, lowland to medium dry land dry climate and wet climate.

\section{References}

1. B. Irianto, A.J. Rieuwpassa, S. Bustaman, E. Waas, Characterization of Maluku Agroecological Zones, Island Clusters I and II, in Proceedings of the Results Agricultural Study for the Fiscal Year 1997/1998, BPTP Maluku, Ambon, Indonesia (1998).

2. A.J. Rieuwpassa, B. Irianto, S. Bustaman, E. Waas, Characterization of Maluku agroecological zones: Island Clusters IV - VIII, in Proceedings of the Results Agricultural Study for the Fiscal Year 1997/1998, Book II, BPTP Maluku, Ambon, Indonesia (1999).

3. J.R. Lalopua, R.E. Wattimena, A. Waksen, S.H.T. Raharjo, Research on root crops at the Faculty of Agriculture, Pattimura University, in Seminar on Potential Development of Tuberous Plants, 31 October 1989, Ambon, Indonesia (1989)

4. Rostiwati, Large-scale planting of sago (Metroxylon sago Roettb) (Forestry and Plantation Research and Development Agency. Jakarta, 2009)

5. T.E. Harijono, M.W. Apriliyanti, A. Afriliana, J. Kusnadi, Inter. J. Pharm. Tech Res. 5, 4 (2013)

6. E. Sulistyono, J. Marpaung, Indonesian J. Agron. 32, 2 (2004)

7. T. Ranistia, Gembili. http://tiaranistia.blogspot.com/2011/03/makalah-gembili.html [Accessed 18 November 2020]

8. A. Rudiyanto, Gembilis as a food potential in Indonesia. https://biodiversitywarriors.org/m/article.php?idj=3627 [Accessed 18 November 2020]

9. A.Y. Prabowo, T. Estiasih, I. Purwatiningrum, J. Food and Agroindustry. 2, 3 (2014)

10. M. Azhar, J. Sci. Tech. 12, 1 (2009)

11. M. Setyowati, Indonesia Germplasm News, 28 (2016)

12. C. Ana, Four benefits of umbi gembili for humans. https: //benefit.co.id/benefits-umbigembili [Accessed 20 November 2020].

13. M. Sabda, H.S. Wulanningtyas, M. Ondikeleuw, Y. Baliadi, Bul. Plasma Nutfah, 25, 1 (2019)

14. Y.D. Printa. Thesis Faculty of Industrial Technology, UPN Veteran (East Java, 2010)

15. Trustinah, A. Kasno, Uwi-uwian (Dioscorea), http: //balitkabi.litbang.-pertanian.go.id/ infotek/uwi-uwian-dioscorea-food-alternatives that have not been widely exploited [Accessed November 20, 2020]

16. A. Subagio, E. Ginting, Trustinah, N.N. Herlina, Exploration of water-soluble polysaccharides of gembili (Dioscorea esculenta L.) and their applications for food products. http: //www.litbang.pertanian.go.id/ks/one/326/file/- explorationpolysaccharide [Accessed November 20, 2020] 
17. P. Lingga, B. Sarwono, F. Rahardi, P.C. Rahardja, J.J. Afriastini, R. Wudianto, W.H. Apriadji, PT Penebar Swadaya, Jakarta (1992)

18. J.B. Alfons. Roots Technology Innovation Supports Food security. National Seminar Acceleration of Location-Specific Agricultural Technology Innovations to Support Food Security in the Archipelago Region, BPTP Maluku - Provincial Government - Pattimura University, (2016) 